\title{
COMMUNITY GARDENS AND FOOD SECURITY IN RURAL LIVELIHOOD DEVELOPMENT: THE CASE OF ENTREPRENEURIAL AND MARKET GARDENS IN MBERENGWA, ZIMBABWE
}

\author{
Bernard Chazovachii, Cephas Mutami, Lecturers \\ Department of Rural and Urban Development, Great Zimbabwe University, Zimbabwe \\ E-mail: bchazovachii@gmail.com, cmutami@gmail.com
}

\author{
John Bowora, Lecturer \\ Department of Rural and Urban Planning, University of Zimbabwe, Zimbabwe \\ E-mail: johnbowora@gmail.com
}

\begin{abstract}
This paper seeks to assess the contribution of community gardens on food security in rural livelihoods development in Mberengwa ward 27. Despite the introduction of community gardens in ward 27, poverty persisted amongst the vulnerable groups in the district. Both qualitative and quantitative methods were used in collection of data through questionnaires, interviews and focused group discussions (FGDs). Analysis was done using descriptive statistics and content analysis. This study revealed that the vulnerable people of Mberengwa derived income, basic horticultural skills, enriching their garden soils and food commodities from the Imbahuru community garden. Factors like all year-round production of crops, intensiveness of the activity, monitoring and evaluation by extension workers, field days in all seasons and demand of the crop varieties grown influence food security in the district. However challenges persisted due to their seclusion of these gardeners from credit facilicities, lack of irrigation equipment, unstable power relations among leaders and the project was associated with the weak in society. The research concludes that the gardening project should be done not in isolation with the Zimbabwe's agrarian reform programme which would provide all forms of capital which capacitated the vulnerable rural dwellers.
\end{abstract}

\section{KEY WORDS}

Community gardens; Vulnerability; Livelihoods; Food security; Sustainable rural development.

Community gardens were initiated back from the eighteenth and nineteenth centuries where tropical veg culture survived in remote areas and mixed gardens in south East Asia (Grigg, 1974). According to Taylor and Francis (2009) community gardens in Africa involved irrigation in home gardens since prehistoric time with the provision of vegetables for household consumption. The goal of community gardens was to increase household and intra household food security throughout the year. Community gardens provide marketing opportunities to rural people and built a base for food production for the vulnerable. Recently mass establishment of community gardens was done by non-governmental organisations namely Action Faim and CARE Zimbabwe in a bid to maintain sustainable rural livelihoods among the rural households.

Communities have been upgrading communal gardens by selling the surplus production to obtain household income. Auret (1990) revealed that NGOs assist in establishing small irrigated vegetable gardens as they are a major component for the daily food consumption. In 2006, CARE Zimbabwe assisted in establishing community garden projects in Mberengwa ward 27, Imbahuru Community Garden to accommodate the vulnerable groups to alleviate rural poverty. Community gardens promoted food security as children and elderly participate in this field agriculture,(World Bank, 2007).Since the inception of community garden projects in Mberengwa ward 27 there is persistent food insecurity derailing sustainability of other livelihood activities. The problem this study seeks to address is the increasing in poverty among the vulnerable groups despite, the introduction of community gardens in Mberengwa ward 27 by CARE to reduce poverty. The garden projects were supposed to offer food security among the households but the real poor are still in 
shocks and stress. The goal of sustainable rural livelihoods remained elusive due to inherent factors challenging community gardens as a rural livelihood strategy. It is the aim of this project to unearth why poverty is growing despite the introduction of community gardens and examine the coping strategies used as solutions to the challenges faced in community garden projects.

Community Gardens. According to Middleton (2009), community gardens are a place to grow food crops, flowers and herbs in the company of friends and neighbours. It may also be a place to reconnect with nature or get physical exercise. Basing on this definition community gardens have attracted different meaning, uses, and purposes to different societies and communities. As a result some use community gardens because they lack adequate space at their homes to have a garden and to build a sense of community among neighbours (Middleton, 2009). In rural areas, community gardens takes different shapes, forms and sizes and purposes that make them differ from each other and from place to place. Community gardens are innumerable i.e. neighborhood community gardens, Youth Communal gardens and School gardens, Nutritional gardens, Entrepreneurial and Market gardens, Home gardens, Therapy gardens and Demonstration gardens.

Neighborhood community gardens as eluded by Middleton, (2009) are located on land that is divided into different plots for individuals or families. These gardens have leaders, committee for management and can be found at churches. In Zimbabwe they are found in wetlands as dambos distributed by headmen for each household (Leach, 1990). Crops such as maize, sorghum, vegetables and bananas are found in these gardens. Youth and School gardens are found in schools for educational purposes to young people. They are located at a community centre for the unemployed youths to earn a living. At schools they provide classroom lessons in different subjects such as agriculture and science subjects. Species such as vegetables, groundnuts, beans, maize, and tomatoes are found in these gardens.

Nutritional gardens are funded by NGOs through the ministry of health and land is allocated to the vulnerable groups in order to offer supplementary diets to everyday meals. Green vegetables, onion and carrots are mainly found and especially medicinal plants, (Moyo and Tevera, 2000).

There are also Entrepreneurial and Market gardens which specialized to improve market and are established by non profit organization to teach business and job skills to youth and vulnerable groups. The participants are paid by money after sales, (Middleton, 2009). Crops mainly found in these gardens are vegetables, fruit trees like oranges and avocados and also cash crops which are coconuts and sugarcane.

Home gardens take different size and activities. They are called small gardens or kitchen gardens located near the homestead specifically for vegetables and water for irrigation can be obtained from dish washing and bathing. They are mostly found in arid and semi arid areas in sub Saharan Africa. They may also take gardens plot and may be communally owned, (Taylor and Francis, 2009). Home gardens can take a form of nurseries to provide seedlings, floriculture with ornamental plant located in peri-urban for market and they can also be home market gardens. According to Rangasamy et al (2002) these may be called forest gardens found in the humid tropics integrating poultry, vegetables and fruit trees hence mixed gardens.

Communal gardens are located in a communal centre, organized and managed by a community group to share work and rewards. They own the land collectively and share the proceeds among members. They can donate to food pantry what they harvest at their pleasure. Communal gardens can accommodate at least thirty people up to more than two hundred people. Different types of crops are grown such as cereals that are maize, sorghum, cash crops, timber, forage, fruit trees and different types of vegetables.

The food bank normally dominated these gardens and located at a food pantry. Food bank and pantry are for storage facilities and volunteers are participants or food pantry clients who grow and donate to the food pantry. Mainly cereals such as maize, nutritional crops like beans and peas are grown in these gardens.

Therapy gardens are mainly for horticultural therapy to hospital patients, located at hospitals, prisons and senior caters. A horticulture therapist leads programs and activities. 
Horticultural plants are cultivated in these gardens such as ornamental crops, herbs, medicinal plants, flowers, garlic and different types of vegetables.

Lastly, Demonstration gardens located at working community gardens managed and maintained by the public while led by extension master gardeners. Community members are trained as volunteers to educate the public about gardening. Different crops of interests may be chosen for example a cereal, vegetable, fish, fruit tree or horticultural products on how it is cultivated. This study would focus on Entrepreneurial and Market gardens with the use of Imbahuru community garden in Mberengwa district. Imbahuru community garden has proved to be a livelihood which is sustainable, cope with and recover from stress and shocks, maintain or enhance its capabilities and assets, and provide sustainable livelihood opportunities for the next generation, and which contributes net benefits to other livelihoods at the local and global levels in the long and short term, (Ellis, 1998). A method of selecting beneficiaries in community gardens is limited to social and technical criteria. Local community based organizations play an important role in selecting beneficiaries. According to Eshtayeh and Earis (2006) women are invited to a meeting in which information is collected from the community based organizations (CBOs) representing the CBOs but also from the public to foster transparency. Moyo and Tevera (2000) noted that in national gardens which are funded by Non governmental organizations (NGOs) through the ministry of health, the councillors who are recognized political leaders allocated land for gardens. This created conflicts with traditional leaders.

Nutritional gardens normally favor the sick to get balanced diet mostly those with chronic diseases like tuberculosis, AIDS and others .NGOs collect information about the living standards, family size, assets and choose according to the vulnerability context of that communal area.

Community gardens have important resources with socio-economic reproduction roles for the communal people (Moyo and Tevera, 2000).Some villagers have resorted to gardening while waiting for the rain season and they make profits using them for accessing inputs during the main season of farming (New farmer, 2004).Some A1 resettled farmers in Shamva who have no adequate irrigation facilities have opted for gardening instead of irrigation schemes because of their huge profits. Huge profits are being made from gardening by selling their crops to Mbare musika and along Shamva road (New farmer, 2004).

Scoones (2010) postulated that gardens have benefited women through specialization and they obtained vegetables, groundnuts and Bambara nuts for the household food consumption. .Community have benefited from participation in those gardens where they derive their income. .Community run schemes have performed better than government managed schemes because of their flexibiliity, lower cost of operation and participation of women (Rukuni et al 2006). Community gardens in rural areas utilized wetlands as source of water to irrigate their crops and vegetables. These wetlands existed together with community gardens for many years and proved to be highly productive as they contribute to social and economic welfare of many rural families, (Rukuni, et al 2006). The use of wetlands to vegetable gardening is increasing in small holder farmers.

More so, community gardens contribute to the affected and vulnerable household's food security. Implementing organizations are helping promoting vegetable gardens to help vulnerable groups and affected households get access to vegetables to ensure food and nutrition security (FAO, 2002). These nutritional gardens have benefited households and chronically ill people with herbs and vegetables as they improve their nutrition throughout the year. These are also activities for women where income generation becomes easy for them. Medical plants found in these community gardens such as garlic and onions have role of treating HIV related symptoms, improving digestion and stimulating appetite (FAO, 2002). Gardens are for income generation and food producing activities. These are necessary for the contribution to food security and safety. Over 2, 8 million dollars worth of food was produced from the subsistence gardens during the depression end by the time of second war, and the food administration set up a nutritional victory garden programme which saw huge benefits, (FAO, 2002). 
Although other community gardens are illegally located along river banks they have supported families through income and food throughout the year, (Scoones, 2010). Microirrigation has been also more successful with gardens being the source of year around vegetables and maize. These are found in resettlements and are an important basis for livelihood strategies (Scoones, 2010).

Communities have upgraded gardens and individuals from these gardens sell surplus produce to obtain household incomes which in turn cater for household food security, basic and other emergencies. Community gardens benefited the communities to build social networks through sharing gardening activities .According to Moyo and Tevera (2000) family and kinship act as the distributive mechanisms as well as promoting interpersonal relations and social identity of individual members. This mainly happen in sharing dambo gardens among the families who participate .Gardens have promoted intermarriages between the families and thereby building networks of kinship, (Moyo and Tevera, 2000).

Community gardens act as a survival strategy for the poor in many communities to share resources together in order to meet their daily basic needs and mutual obligations. Preservation of aesthetic and cultural values is demonstrated in Asian gardens. Home gardens were also useful in the slavery stage and were influenced by African slaves in Caribbean as food used by poor people as a strategy against food inflation resulting from heavy reliance on imported food.

Challenges in Community Gardens. Community gardens face many challenges that limit their production and interaction between members. Lack of irrigation equipment undermined the ability of poor households to raise their agricultural incomes and made them even more vulnerable to frequent droughts. Power relations are an impediment to the success of gardens. These relations determine the controls of gardens (Moyo and Tevera, 2000). There are also illegitimate forms of transferring land or selling of land or expansion of plots which is common in dambo gardens. According to Moyo and Tevera (2000) this was as a result of usurpation of powers of traditional leaders to manage land and other natural resources lead to protest against rules.

According to Middleton (2009) community gardens in rural areas face management challenges. Most of the participants in community gardens lack gardening skills. Community gardens attracted members which are political motivated and they tend to influence decision making. Middleton (2009) also noted that community gardens also face the challenge of water to irrigate fruits and vegetable during summer. Conflicts over control of land, competition between actors over use of scarce resources such as water because of population pressure are also common in community gardens .According to Moyo and Tevera (2000) there are conflicts between national institutions and local people for example national institutions restrict the cultivation of dambo gardens using national institutions.

\section{METHODOLOGY}

Both qualitative and quantitative data were utilized in this research. A descriptive survey design was adopted which incorporated questionnaires, interviews ,secondary data sources and focused group discussions to collect data about selection of beneficiaries, benefits, challenges and coping strategies in community garden projects from beneficiaries, local authorities, locals and leaders. Random and snowball sampling were employed in the study of community gardens in Mberengwa. A sample of forty garden beneficiaries was selected using this procedure. Purposive sampling technique /Snowball were used because a detailed data from a few cases was needed as the research focused on in-depth information which was generated from respondents. This procedure was used to select garden committee, local leaders as introduced by an AGRITEX extension worker of the garden. The extension worker was targeted and introduced other potential respondents with relevant information on the community garden. Triangulation, descriptive statistical and content analysis was used for data analysis. 


\section{RESULTS AND DISCUSSIONS}

Vulnerability Context of the Mberengwa Rural Households. In Mberengwa, Zimbabwe, gold panning was an alternate of agriculture just as most of the Sub Saharan African countries. It provided a safety net to Zimbabwe livelihoods as they could no longer stand the hunger and food shortages created by drought, inflation and Structural Adjustment Programmes among other factor (Clemens and Moss 2005, Mawere, 2011). Since 2000, the livelihood situation in Zimbabwe has taken a turn for the worse. By mid-2005 the local currency had lost 99\% of its value (Clemens and Moss 2005, Mawere, 2011), incomes in real terms had tumbled by over $98 \%$ compared to their 1990 value wiping out the income gains of the past 52 years; (EIU 2006:27, Mawere, 2011) unemployment, poverty and the cost of living had all sky rocketed to unprecedented levels (Gono 2005, Mawere, 2011). By the end of 2006 inflation was over 1280 percent (Gono 2007; 24, Mawere, 2011) latest estimated employment is put at $70 \%$ and the poverty head count ratio at $70 \%$ (IMF 2005, Gono 2007, Mawere, 2011). Gardening has been one of the few coping strategies employed by a large remote poor and uneducated section of Zimbabwe.

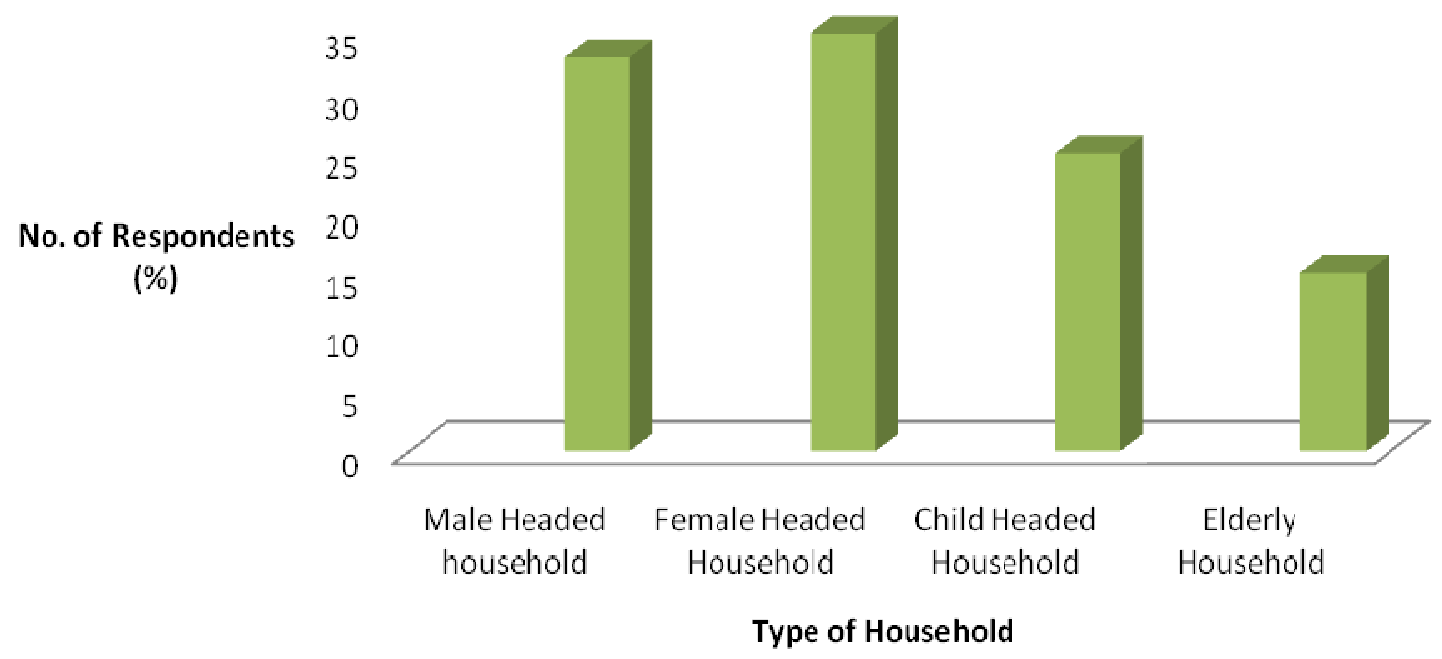

Figure 1. Social Vulnerability of households in Mberengwa Source: Fieldwork 2012

Figure 1 shows the households which adopted conservation agriculture $68 \%$ were socially vulnerable. This creates an impression that conservation agriculture is viewed as a farming method of the poor which is backward unproductive. The study also revealed that even those households (about $53 \%$ of total households in Mberengwa) which practice conservation agriculture they do so as a mixed practice with other convectional farming systems like ox-drawn ploughing for a few acres. The fact that most households which engage in conservation agriculture are poor mean that the real effectiveness of the practice may be difficult to realize as most of them cannot afford to purchase certified seeds on an annual basis and lack some basic tools required for the practice (Chazovachii, et al unpublished,2012).

The vulnerability context of families in the Mberengwa rural district is one with the villagers exposed to droughts and high temperatures. These have defined the nature and severity of the impacts of the physical and socio- economic conditions prevailing in Mberengwa. The climate change and the series of droughts victimize the people of Mberengwa. 


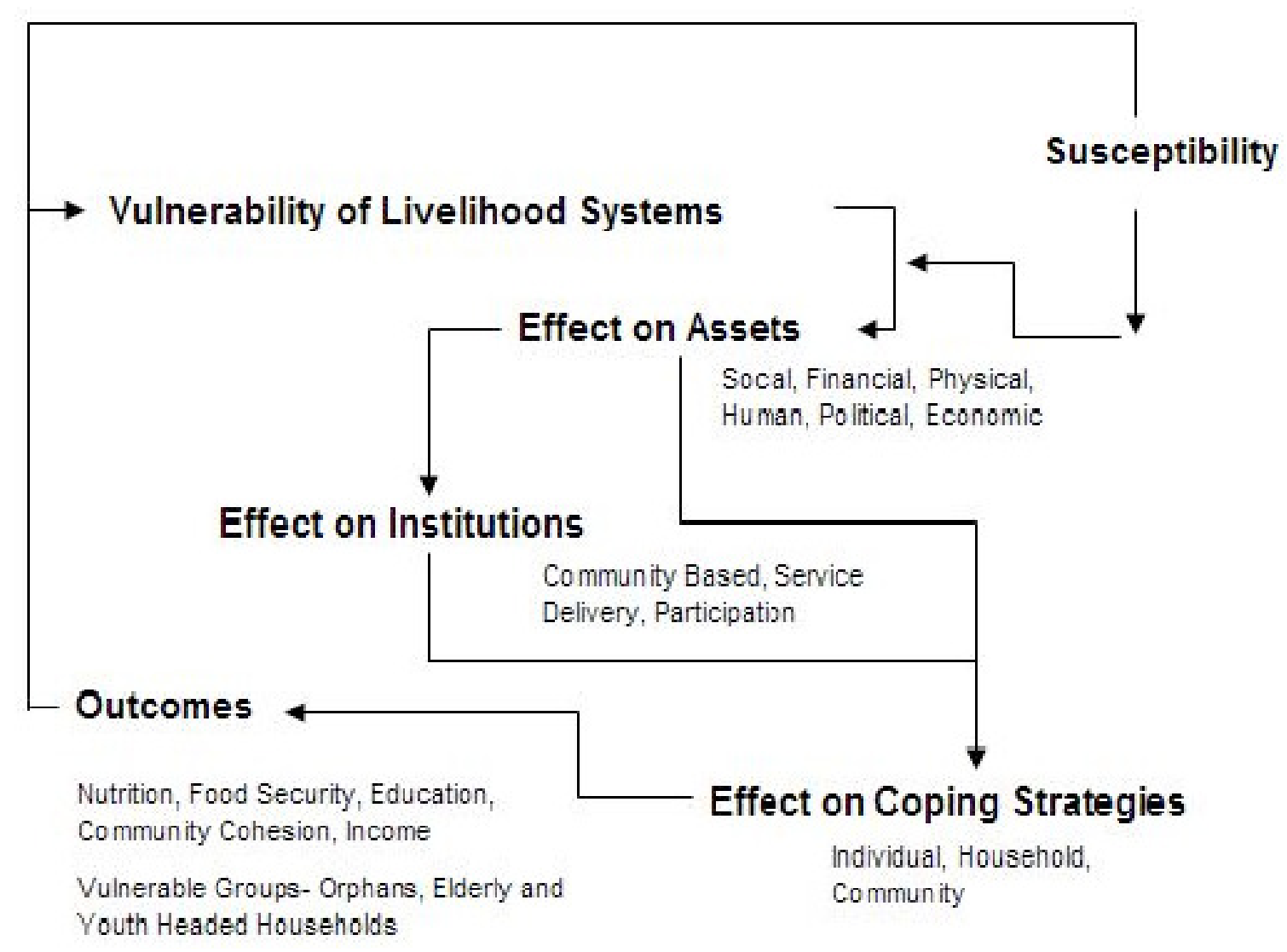

Figure 2. Scheme adopted from Mawere, 2011

The above diagram indicated that the majority of gardeners derive about $\$ 45$ to $80 \%$ per annum and about $10 \%$ of respondents derive more than $\$ 115$ per annum.

The majority of the respondents indicated that income derived from selling garden produce was used to buy grocery and food, followed by other emergencies, agriculture utensils, fees, clothing and livestock and lastly grinding mill charges. This is because those gardeners earn little income and moneys are not meaningful for purchasing huge assets per annum. Hence income is mainly used to buy cheaper products for daily use especially food and groceries.

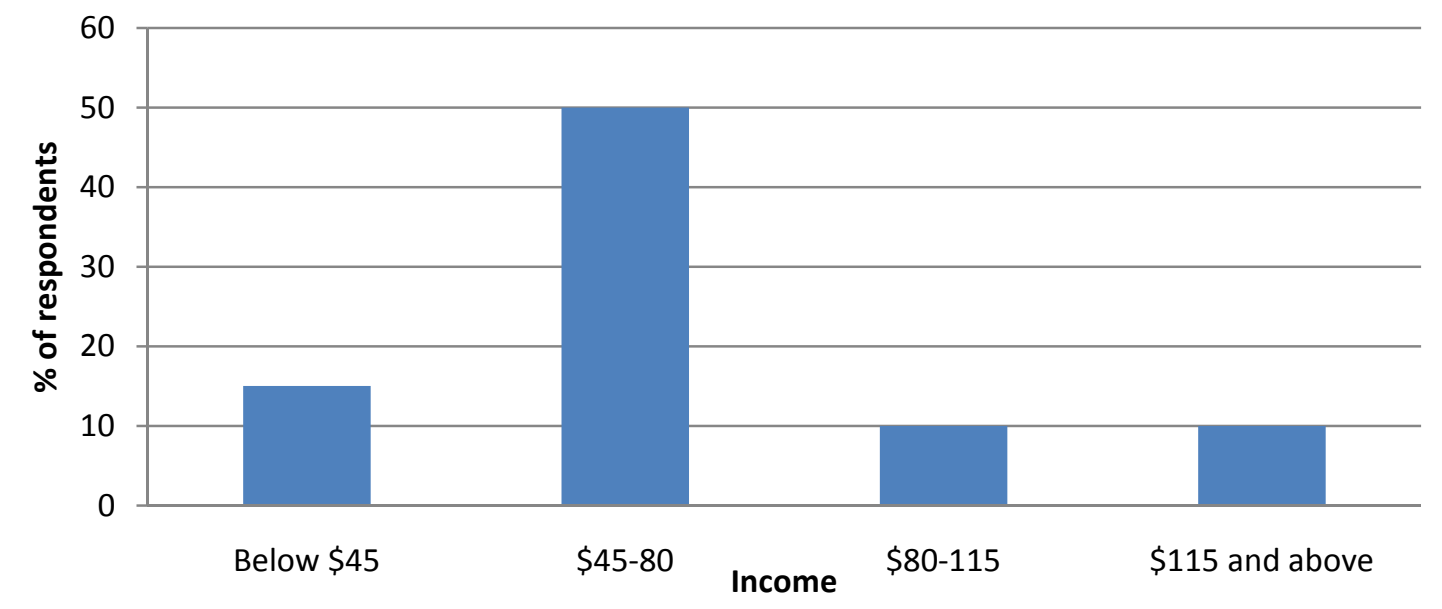

Figure 3. Income of respondents per year Source: field survey, 2012 


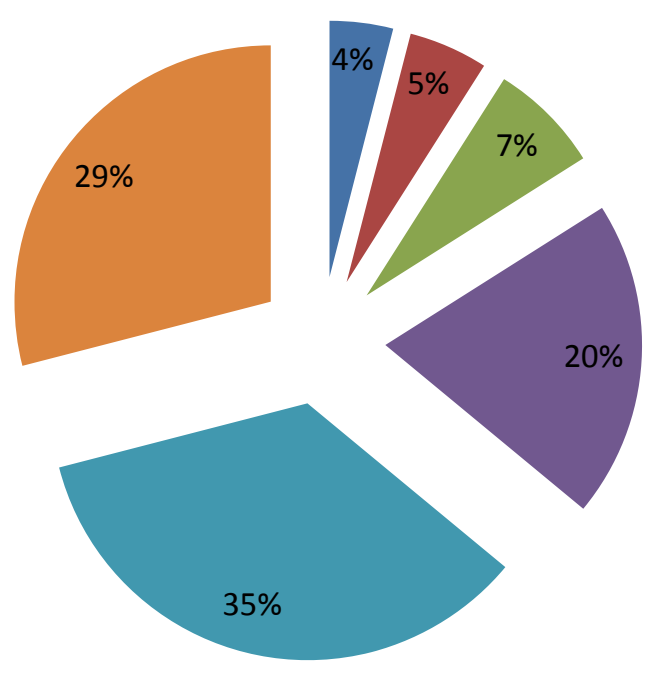

\author{
grinding mill charges \\ clothing and livestock \\ school fees \\ agriculture inputs and utencils \\ grocery and food \\ other emergences.
}

Figure 4. Assets from income

Source: field survey, 2012

Towards Sustainable Livelihood Development through Community Gardens. The term sustainable livelihoods relates to a wide set of issues which encompass much of the broader debate about the relationships between poverty and environment, (Scoones, 2010). Chambers and Cornway, (1991) state that livelihoods comprise of the capabilities, assets (both material and social resources) and activities required for a means of living. A livelihood is sustainable when it can cope with, and recover from, stresses and shocks and maintain or enhance its capabilities and assets both now and in the future. In an attempt to make a living, people use a variety of resources such as social networks, capital knowledge and markets to produce food and marketable commodities and to raise their incomes, (Herbinck and Bourdillon 2001, Mutangi, 2010). However when such resources are not available or when they are undermined people tend to go under stress and shock. This can be traced to Sen's theory of entitlements, which postulates that the purpose of development is to improve human lives through expanding the range of things a person could do and be, for example, being healthy and well nourished, being knowledgeable and being able to participate in the life of the community. Development is thus about removing obstacles to what a person can do in life for example illiteracy, ill health, lack of access to income and employment opportunities, lack of civil and political freedoms, (Zimbabwe Human Development Report 2003). Before the inception of the garden, the people of Mberengwa were suffering from malnutrition and kwashiorkor due to shortage of proteins in their diets. As a result gardening brought about rich protein crops such as beans, peas and potatoes. According to FAO (2002) community garden constituted the affected and the vulnerable groups promoting vegetable garden to ensure food and nutrition security, providing medical role of treating HIV related symptoms and improving digestion and stimulate appetite. This was also witnessed from the Imbahuru garden as the crops like garlic are found in the garden and respondents disclosed that they have better diet in their daily consumption.

Many households indicated the changes in their quality of life since the inception of community gardens. They obtained basic food commodities like relish and spices for their meals. They have gained skills through workshops conducted for farming purposes which help them to practice good methods of farming and cooperative efforts as they enhanced attitudes interdependency.

Respondents also indicated that they were gaining team spirit, financial transactions and reduced crime as the locals spend their time in gardening activities. Community gardening become a meeting point for formation clubs and helps to reduce stress as 
gardeners exchange ideas and knowledge. Moreover, gardeners enhanced community participation in their projects and improved social ties, networks and relations through interaction and by borrowing produce, equipment and sharing moral obligation that improves unity in their community. Other respondents indicated that they have gained teachings about HIV and AIDS while working in the gardens. As a result gardening was seen as centre for practicing cultivation of different crops from different corners of the world hence reduces laziness, dependency and promotes diligence, leadership practice and identification of talents. Therefore community gardens proved to have different benefits as witnessed by people of Mberengwa.

Factors Influencing Food Security in Community Gardens. The community garden activity is an all year round enterprise. This on its own makes the project sustaining to rural households. This would be an assurance that something is going to come out be it winter or summer season. Coupled with that, the crop varieties grown are those that would be on high demand like fresh ground nuts, round nuts and other vegetable varieties in to an extent that market is readily available. The role of extension officers in monitoring and evaluation of the activities in the gardens has placed them at the level of intensive small scale commercial farmers that production is being realized. Field days are promotional days that encourage competition and motivation among the gardeners to an extent that it boosts future productions in their gardens.

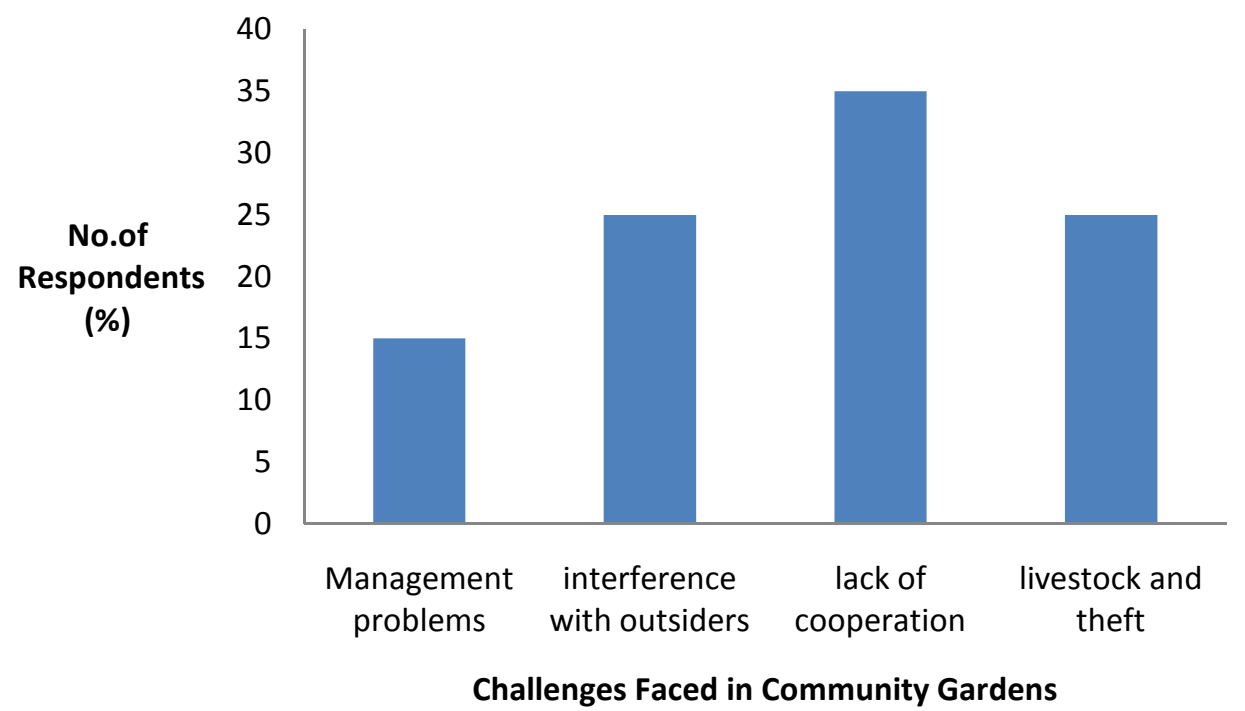

Figure 6. Challenges Faced in Community Gardens Source: field survey, 2012

The majority of respondents indicated that there is lack of cooperation among gardeners; as a result the communal spirit is affected hence reduced production in gardens. Interference with other outsiders who vandalize fencing followed by livestock and theft affecting their produce were some of the challenges. Wild animals such as baboons devour garden crops. Finally respondents showed that they suffer from poor management as leadership lacks knowledge and skills. As Middleton (2009) alludes community gardens in rural areas face management challenges as they are management intensive, time and capacity to work and organize people to resolve conflicts becomes problematic. The gardeners also reported that chemicals were lacking to treat their crops resulting in poor harvests. Gardeners were struggling to mobilize finances together for buying chemicals. This is because CARE which was helping them in gardening activities handed over the project to the community hence failed to properly manage.

Marketing Challenges. The majority of respondents indicated that they have on access to buyers, long distance to market and high transport costs. This is probably due to lack of strategic marketing points where their produce can fetch meaningful prices, and they 
are competing with other community gardens, in their ward, nearest gardens and home gardens for market. As a result price for inputs where not in commensuration with income after selling their produce.

Coping Strategies. The majority of the respondents indicated that they have set up three sub-committees on top of the main committees; which are marketing, agronomy and security. The committees were set as to solve the challenges that are likely to occur and to reshuffle committees every year so as avoid conflicts. However other gardens relied on kinship and build friendships. Moyo and Tevera (2009) noted that as the coping strategy in the community, other gardens engage in intermarriages to build network of kinship as sources of cooperation as pre-conflict resolution.

\section{CONCLUSION}

The people of Mberengwa benefited the socio-economic services from gardening as it continued to be the source of income for the beneficiaries of community. The income derived has been used for paying school fees, buying assets, agricultural inputs and buying groceries and food. Evaluations have confirmed that the benefits resulted in improvement in the quality of life of the rural people. Field days, monitoring and evaluation by extension workers, and the practice of gardening all year-round has transformed gardening to sustain food security in the district. Social benefits like social networks, physical exercises, team spirit and stress reduction and community participation are important for community building and livelihood development.

The challenges being faced in community gardens are theft, poor management and marketing problems. Challenges such as conflicts and power contestations are inherent and measures are needed to solve such problems as they contribute to community breakdown. There should be an increase in community participation through the introduction of other subsidiary projects linked to gardening such as orchard to enhance diet, household income and capacity to absorb shocks and trends like droughts and climatic change. There is need for desplinary committee to control behaviour and conflicts in community gardens. The gardening project should be done not in isolation with the Zimbabwe's agrarian reform programme which would provide all forms of capital which capacitated the vulnerable rural dwellers to enhance food security.

\section{REFERENCES}

[1] Auret, D. (1990). A Decade of Development in Zimbabwe 1980-1990. Gweru Mambo Press.

[2] Chambers and Conway, G (1991). Sustainable Rural Livelihoods: Practical Concepts for the $21_{\text {st }}$ Century. IDS Discussion paper, no. 296. Institute of Development Studies.

[3] Chazovachii, B., Mutami, C. and Phikelele, S. (2012). Mechanized Conservation Agriculture and Food Security in Mberengwa District, Zimbabwe. Unpublished.

[4] Ellis, F. (1998) Survey Rural Livelihood Diversity in Developing Countries: Analysis, Policy, Methods. Oxford, Oxford University Press.

[5] Eshtayeh, I. and Earis, R. (2006) Lessons learned in how to select Female beneficiaries: Backyard agricultural production and Cottage industry activities for women, Rome. FAO.

[6] FAO (2002) Migrants' Long Distance Relationships and Social Networks in Dakar: Environment and Urbanization, Rome, FAO.

[7] Grigg, D.B. (1974) The Agricultural Systems of the world: An Evolutionary Approach., New York, Cambridge University Press.

[8] Leach, M (1990) Social Organization and Agricultural Innovation: Women's vegetable Production in Eastern Sierra Leone, Peasant Household Systems. International workshop proceedings.

[9] Local Harvest (2009) Challenges and Solutions to Community Gardens: Alternative Communal Farmer/WPB-FL, Florida. 
[10] Mawere, M. (2011) Gold panning in Central Mozambique: A Critical Investigation of the Effects of Gold Panning in Manica.IJOPAGG.

[11] Middleton, J. (2009) Community Gardening. Columbia, University of Missouri.

[12] Moyo, S. and Tevera, D. (2000) Environmental Security in Southern Africa. Harare, SAPES Trust.

[13] Mutangi, G. (2010). 'The changing patterns of farm labour after the Fast Track Land Reform Programme: The case of Guruve District'. Livelihoods after Land Reform in Zimbabwe Working Paper 13. Livelihoods after Land Reform Project. South Africa: PLAAS.

[14] New Farmer (2004) Zimbabwe's Leading Voice of Agriculture: Volume 9 number 4 Harare, Ministry of Agriculture.

[15] Rangasamy, A. et al (2002) Farming Systems in the Tropics, New Delhi, Kalyan publishers.

[16] Rukuni, M. et al (2006) Zimbabwe's Agricultural Revolution Revisited, Harare, UZ Publications.

[17] Scoones, I. et al (2010) African Issues: Zimbabwe's Land Reform: Myths and Realities. Harare, Weaver Press.

[18] Taylor and Francis (2009) Traditional Home Gardens and Rural Livelihoods in Nhema, Zimbabwe: A Sustainable Agro forestry System, Volume 16, Issue 1, 2009.

[19] UNDP (1996) Some Basic Facts about Home Gardens, New York, UNDP.

[20] World Bank (2007) Delivering on the Pro-poor Growth. Insights and Lessons from country experiences. Washington DC, Macmillan.

[21] Zimbabwe Human Development Report (2003). Redirecting our Responses to HIV and AIDS; Towards Reducing Vulnerability, the ultimate war of survival. 